\title{
VPLYV PANDÉMIE COVID-19 NA JEDNOTLIVÉ SEKTORY NÁRODNÉHO HOSPODÁRSTVA VO VZŤAHU K ZAMESTNANOSTI
}

\author{
Katarína Štalmachová ${ }^{1}$, Mariana Strenitzerová ${ }^{2}$
}

\begin{abstract}
The COVID-19 pandemic brought rapid and unexpected changes that previous contingency plans and teams were not prepared for. As the pandemic continues to evolve, organizations needed to rethink their business and activities and adapt to the new conditions. Therefore, the aim of the article is to point out the impact of the pandemic in sectors of the national economy and what measures had been taken to maintain employment.
\end{abstract}

Keywords: COVID-19 pandemic, employment, national economy.

\section{Úvod}

Od začiatku pandémie COVID-19 začiatkom februára 2020 boli vo väčšine krajín zavedené rôzne obmedzenia ekonomických aktivít, ktorých hlavným ciel'om bolo zastavit' šírenie vírusu. Opatrenia, ktoré boli vládami prijaté na kontrolu šírenia pandémie majú výrazný nepriaznivý vplyv na hospodárske činnosti a vytvorili novú krízu, o ktorej sa predpokladá, že bude v porovnaní s predchádzajúcimi krízami omnoho rozsiahlejšia. [1] Napríklad v Č́ne prijali úrady sériu opatrení vrátane karantény, sociálneho dištancovania sa a cestovných obmedzení. Aj ked' tieto stratégie účinne riešili kritické situácie, mali negatívny vplyv na ekonomický rast Číny, čo viedlo k prvému štvrt'ročnému poklesu hrubého domáceho produktu od začiatku jeho výpočtu v roku 1992. [2] Intenzita ekonomického vplyvu pandémie silne závisí aj od špecializácie krajiny. Krajiny, ktoré sa spoliehajú viac na činnosti s nízkou produktivitou a s nízkym podielom zamestnanosti sú najviac postihnuté. [3] V dôsledku prijatých opatrení nie je možné vykonávat' bežné obchodné činnosti. Vel'ké množstvo zamestnávatel'ov muselo zavriet' svoje prevádzky, čo malo za následok d'alšie problémy. Zatvorenie obchodu znamená stratu podnikania, a teda aj stratu výnosov. S tým d’alej súvisí negatívny vplyv na zamestnanost' a životné podmienky zamestnancov. [4] $Z$ tohto dôvodu pandémia vo vel'kej miere zasiahla aj trh práce, ohrozila stabilitu pracovných miest a zmenila spôsob vykonávania práce. [5] V kontexte súčasnej krízy umožnila práca na dial'ku čiastočne zmiernit' negatívne dôsledky pandémie vo vzt'ahu k zamestnancom a umožnila im udržat' si prácu a príjem aj v prípade, že sú zavedené prísne obmedzenia. V tomto zmysle práca na dial'ku pomáha zamestnancom, ktorí sú schopní vykonávat' svoju profesionálnu činnost' na dial'ku, vyhnút' sa ekonomickým dopadom krízy. [3] Práca na dial'ku alebo práca z domu nie sú novým fenoménom, ale ich význam v súčasnosti rýchlo rastie. [6] Skúmaním dopadov a dôsledkov pandémie na trh práce sa zaoberá viacero autorov. Béland a kol. skúmali krátkodobé dôsledky pandémie na zamestnanost' a mzdy v USA. [7] Z výsledkov ich

\footnotetext{
${ }^{1}$ Ing. Katarína Štalmachová, Fakulta prevádzky a ekonomiky dopravy a spojov, Katedra spojov, Žilinská univerzita v Žiline,

e-mail: katarina.stalmachova@fpedas.uniza.sk

${ }^{2}$ doc. Ing. Mariana Strenitzerová, PhD., Fakulta prevádzky a ekonomiky dopravy a spojov, Katedra spojov, Žilinská univerzita v Žiline,

e-mail: mariana.strenitzerova@fpedas.uniza.sk
} 
prieskumu vyplýva, že vplyvom pandémie sa zvýšila miera nezamestnanosti, znížil sa pracovný čas a tiež angažovanost' zamestnancov. Ďalej však konštatujú, že pandémia nemala významný vplyv na mzdy zamestnancov. Podl'a d'alších autorov, kríza spôsobená pandémiou vedie vo všetkých európskych krajinách k zvýšeniu úrovne nerovnosti a k chudobe. [8]

$\mathrm{Na}$ Slovensku sa prejavil vplyv protipandemických opatrení v zamestnanosti aj v mzdách a spomalila až zastavila sa ekonomická aktivita podnikatel'ských subjektov vo väčšine odvetví. Podl'a prieskumu Národného podnikatel'ského centra, negatívny dopad opatrení $v$ súvislosti $\mathrm{s}$ pandémiou pocituje až $95 \%$ malých a stredných podnikov v odvetviach, ktorých sa primárne dotýkajú opatrenia vlády. [9] Dosiahnutý prepad hospodárstva a zamestnanosti zarad'uje Slovensko medzi najviac postihnuté krajiny Európskej Únie. Vplyvom núteného obmedzenia podnikatel'skej činnosti a poklesu spotrebitel'ského dopytu zo strany zákazníkov boli mnohí zamestnávatelia vystavení tlaku znižovania nákladov aj formou prepúšs'ania zamestnancov. [10] Podl'a Národnej banky Slovenska pandémia však spôsobila na trhu práce straty viac na príjmovej strane ako v počte pracovných miest. Súviselo to najmä s prepadom počtu odpracovaných hodín. Väčšinu pracovných miest sa podarilo udržat' aj vd’aka prijatým fiškálnym opatreniam. Zároveň však dochádzalo k presunu l'udí do neaktivity a obmedzenie cezhraničnej mobility viedlo k poklesu počtu zahraničných pracovníkov. [11] Vláda SR schválila pre zamestnávatel'ov viaceré druhy štátnej pomoci, ktoré možno rozdelit' na príspevky od štátu, odklad odvodov a opatrenia vo finančnej oblasti. Štátna pomoc formou príspevkov je určená zamestnávatel'om a samostatne zárobkovo činným osobám (d’alej len „SZČO“), ktorí museli svoje prevádzky zatvorit' alebo obmedzit' svoju činnost' na základe rozhodnutia Úradu verejného zdravotníctva SR. V tomto prípade môžu zamestnávatelia požiadat' o príspevok na náhradu mzdy zamestnanca, prípadne paušálny príspevok na náhradu straty príjmu zo SZČO. Štátna pomoc je tiež určená zamestnávatel’om a SZČO, ktorí udržia pracovné miesta aj v prípade prerušenia alebo obmedzenia svojej činnosti počas vyhlásenej mimoriadnej situácie. V tomto prípade môžu požiadat' o príspevok na mzdu zamestnanca. Dalším príspevkom je aj príspevok na náhradu straty príjmu zo zárobkovej činnosti, o ktorý môžu požiadat' SZČO a jednoosobové s.r.o., ktoré nemajú príjem z podnikania. [12]

V porovnaní s d’alšími krajinami, Slovensko prijalo podobné opatrenia, avšak niektoré krajiny prijali aj špecifické opatrenia, ktoré sú menej štandardné. Väčšinou sa jednotlivé krajiny od seba odlišovali vo výške a dĺžke poskytnutej pomoci. Mad'arsko sa od ostatných krajín mierne odlišsovalo, a to najmä tým, že prijímalo skôr nepriame nástroje podpory. Kurzarbeit a práca $\mathrm{z}$ domu počas pandémie a následnej izolácie je využívaná prevažne vo všetkých okolitých krajinách. [10]

\section{Metodológia}

Ciel’om príspevku je poukázat' na vplyv pandémie na zamestnávatel'ov v jednotlivých sektoroch národného hospodárstva z pohl’adu zamestnanosti a zistit', aké opatrenia prijali zamestnávatelia pre udržanie zamestnanosti. Primárny prieskum bol realizovaný elektronickým dopytovaním, ktorého sa zúčastnilo 244 zamestnávatel'ov. Rozdelenie zamestnávatel'ov podl'a jednotlivých sektorov národného hospodárstva, vel'kosti (počtu zamestnancov) a formy podnikania je uvedené v Tabul'ke 1. Odpovede respondentov sú graficky interpretované a hodnoty sú uvádzané v percentách. Zber údajov sa realizoval v období od 14. októbra 2020 do 1. decembra 2020. 
Tabul'ka 1 Štruktúra respondentov podl'a sektorov

\begin{tabular}{|c|c|c|}
\hline \multirow{4}{*}{ sektor národného hospodárstva } & primárny & 29 \\
\hline & sekundárny & 74 \\
\hline & terciárny & 116 \\
\hline & kvarciárny & 25 \\
\hline \multirow{5}{*}{ forma podnikania } & akciová spoločnost' & 36 \\
\hline & spoločnost' s ručením obmedzeným & 198 \\
\hline & komanditná spoločnost’ & 3 \\
\hline & družstvo & 2 \\
\hline & samostatne zárobkovo činná osoba & 5 \\
\hline \multirow{4}{*}{$\begin{array}{l}\text { vel'kost' podl'a počtu } \\
\text { zamestnancov }\end{array}$} & 1 až 9 zamestnancov & 65 \\
\hline & 10 až 49 zamestnancov & 88 \\
\hline & 50 až 249 zamestnancova & 69 \\
\hline & 250 a viac zamestnancov & 22 \\
\hline
\end{tabular}

Zdroj: vlastné spracovanie.

\section{Výsledky}

Prieskum bol zrealizovaný medzi zamestnávatel'mi z rôznych odvetví a sektorov národného hospodárstva. Z výsledkov prieskumu vyplýva, že ekonomická situácia firiem v primárnom, sekundárnom, terciárnom aj kvarciárnom sektore bola ovplyvnená pandémiou. Najväčšie rozdiely možno vidiet' v primárnom a terciárnom sektore, kde až $86 \%$ zamestnávatel'ov uviedlo, že pandémia ovplyvnila ich ekonomickú situáciu. Podobne sú na tom aj zamestnávatelia v sekundárnom sektore. V kvarciárnom sektore uviedlo 55\% zamestnávatel'ov, že ich ekonomická situácia bola ovplyvnená pandémiou, zvyšných 45\% zamestnávatel'ov nebolo ovplyvnených pandémiou.

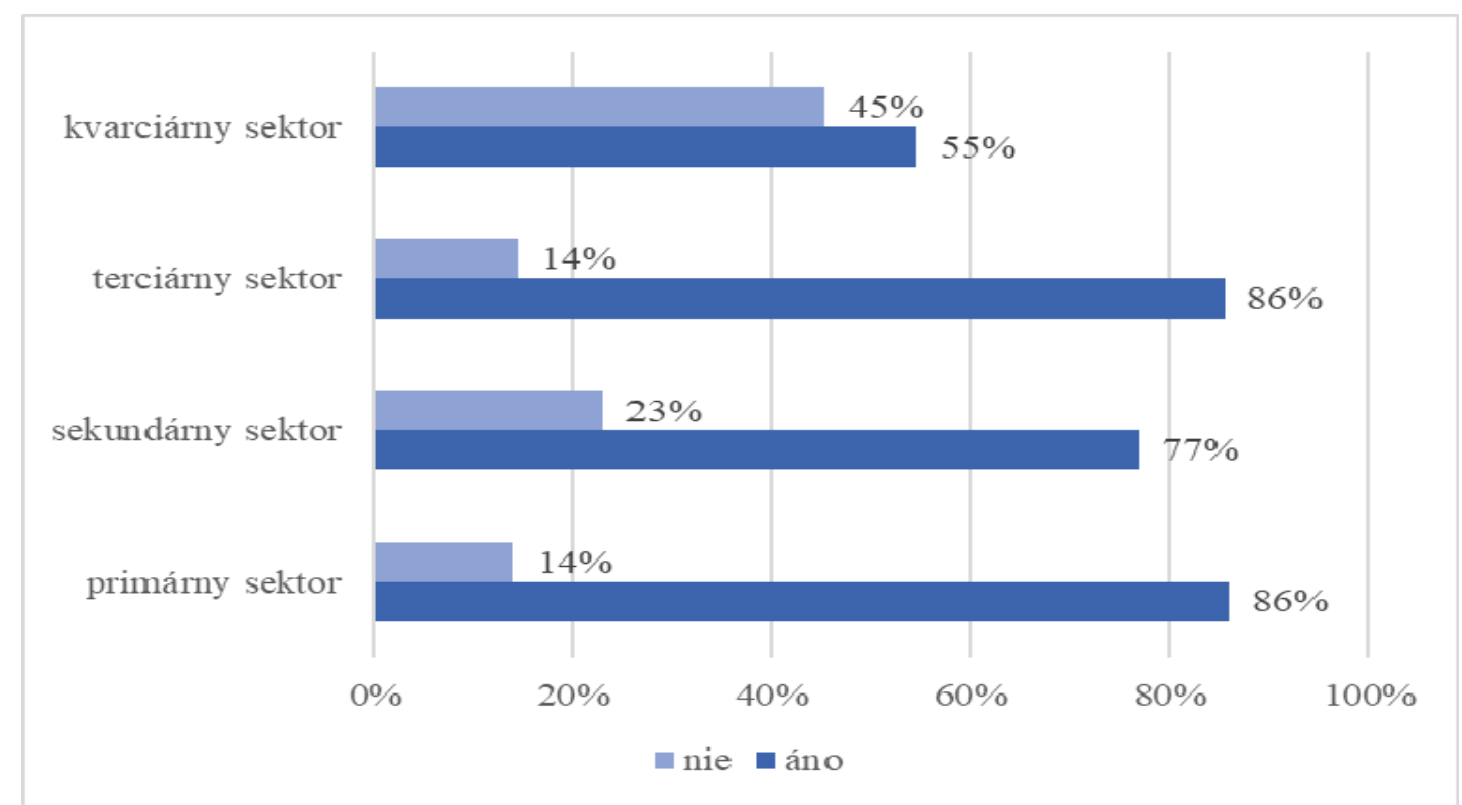

Obrázok 1 Vplyv pandémie na ekonomickú situáciu zamestnávatel'ov.

Zdroj: vlastné spracovanie. 
$\mathrm{Na}$ zmiernenie ekonomických dopadov pandémie boli zamestnávatelia nútení napríklad znížit' mzdy a obmedzit' benefity zamestnancom, obmedzit' nábor nových zamestnancov, prípadne až prepustit' zamestnancov. Niektorí zamestnávatelia zaviedli tiež prácu z domu pre zamestnancov. Len malé percento zamestnávatel'ov uviedlo, že nepristúpili $\mathrm{k}$ žiadnym opatreniam vo vzt'ahu k zamestnancom.

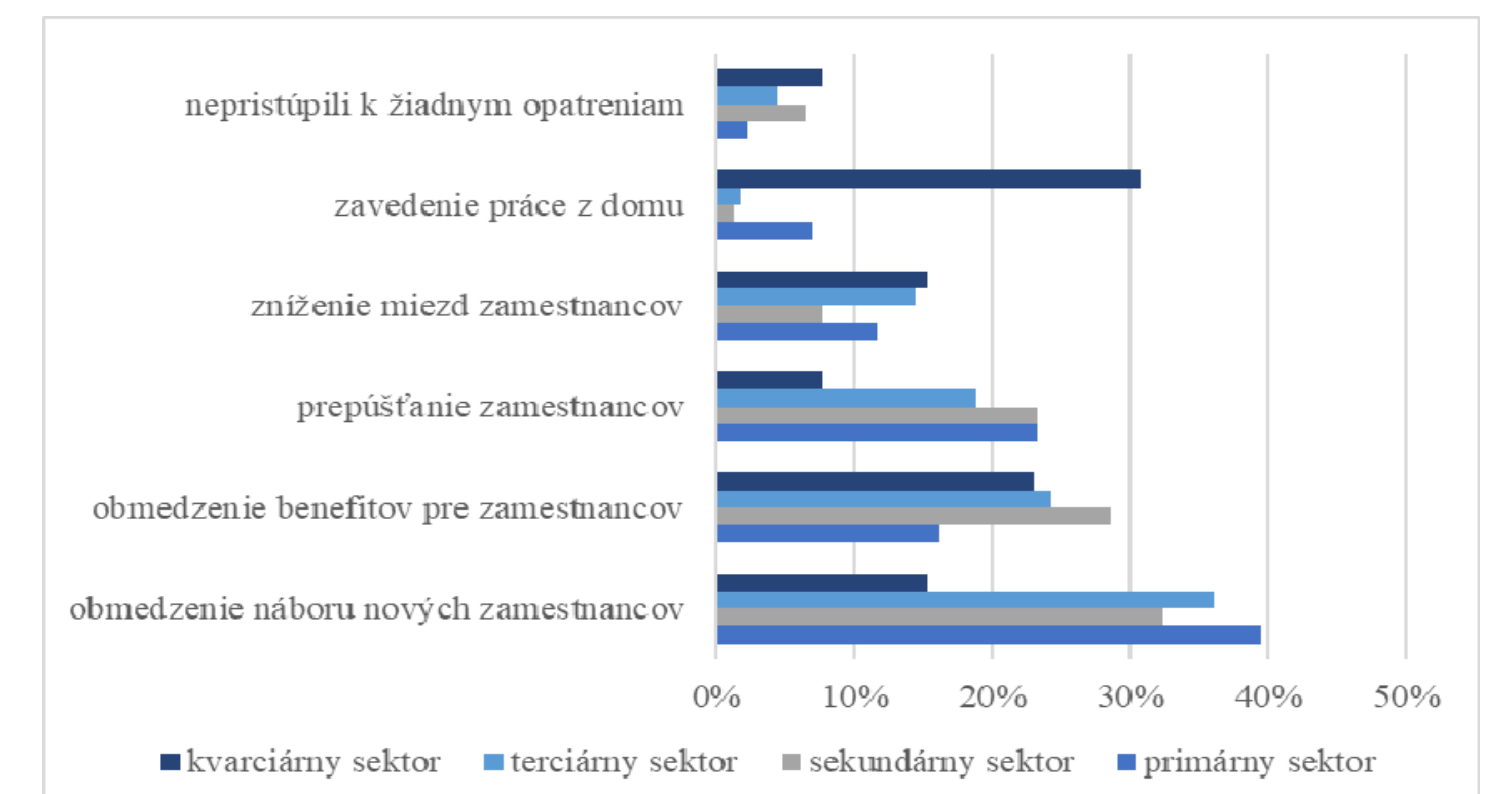

\section{Obrázok 2 Opatrenia na zamedzenie negatívnych ekonomických dopadov vo vzt’ahu k zamestnancom.}

Zdroj: vlastné spracovanie.

Z výsledkov prieskumu vyplýva, že najviac obmedzili nábor nových zamestnancov zamestnávatelia $\mathrm{v}$ primárnom sektore (40\% zamestnávatel'ov), naopak najmenej obmedzili nábor nových zamestnancov zamestnávatelia v kvarciárnom sektore (15\% zamestnávatel'ov). Najviac obmedzili poskytovanie benefitov pre zamestnancov zamestnávatelia v sekundárnom sektore ( $29 \%$ zamestnávatel'ov), najmenej obmedzili benefity zamestnávatelia v primárnom sektore (16\% zamestnávatel'ov). Vo vzt'ahu k znižovaniu miezd zamestnancov je na prvom mieste kvarciárny sektor, kde $15 \%$ zamestnávatel’ov pristúpilo k zníženiu miezd zamestnancov. Najmenej došlo k zníženiu miezd zamestnancov v sekundárnom sektore $(8 \%$ zamestnávatel'ov). Z výsledkov prieskumu tiež vyplýva, že najčastejšie využívajú prácu $\mathrm{z}$ domu zamestnávatelia $\mathrm{v}$ kvarciárnom sektore, naopak najmenej zamestnávatelia v sekundárnom sektore. Uvedený výsledok však môže vyplývat' aj z povahy vykonávaných prác v daných sektoroch. Až $23 \%$ zamestnávatel'ov v primárnom a sekundárnom sektore pristúpilo k prepúšs’aniu zamestnancov, najmenej zamestnávatel'ov pristúpilo k prepúšt’aniu zamestnancov v kvarciárnom sektore ( $8 \%$ zamestnávatel'ov). Väčšina zamestnávatel'ov v primárnom, sekundárnom, terciárnom a kvarciárnom sektore nepredpokladá d’alšie prepúšt’anie zamestnancov (Obrázok 3). Ak aj zamestnávatelia predpokladajú d’alšie prepúšt'anie zamestnancov, v primárnom sektore $14 \%$ zamestnávatel'ov plánuje d'alej prepustit' do $5 \%$ zamestnancov, $57 \%$ zamestnávatel'ov plánuje prepustit' od 5 do $10 \%$ zamestnancov, a nad $10 \%$ zamestnancov plánuje prepustit' $29 \%$ zamestnávatel'ov. V sekundárnom sektore zamestnávatelia plánujú väčšinou prepustit’ nad $10 \%$ zamestnancov, rovnako aj $\mathrm{v}$ kvarciárnom sektore. $\mathrm{V}$ terciárnom sektore plánuje $48 \%$ zamestnávatel'ov prepustit' do $10 \%$ zamestnancov a $52 \%$ zamestnávatel'ov plánuje prepustit' nad $10 \%$ zamestnancov. 


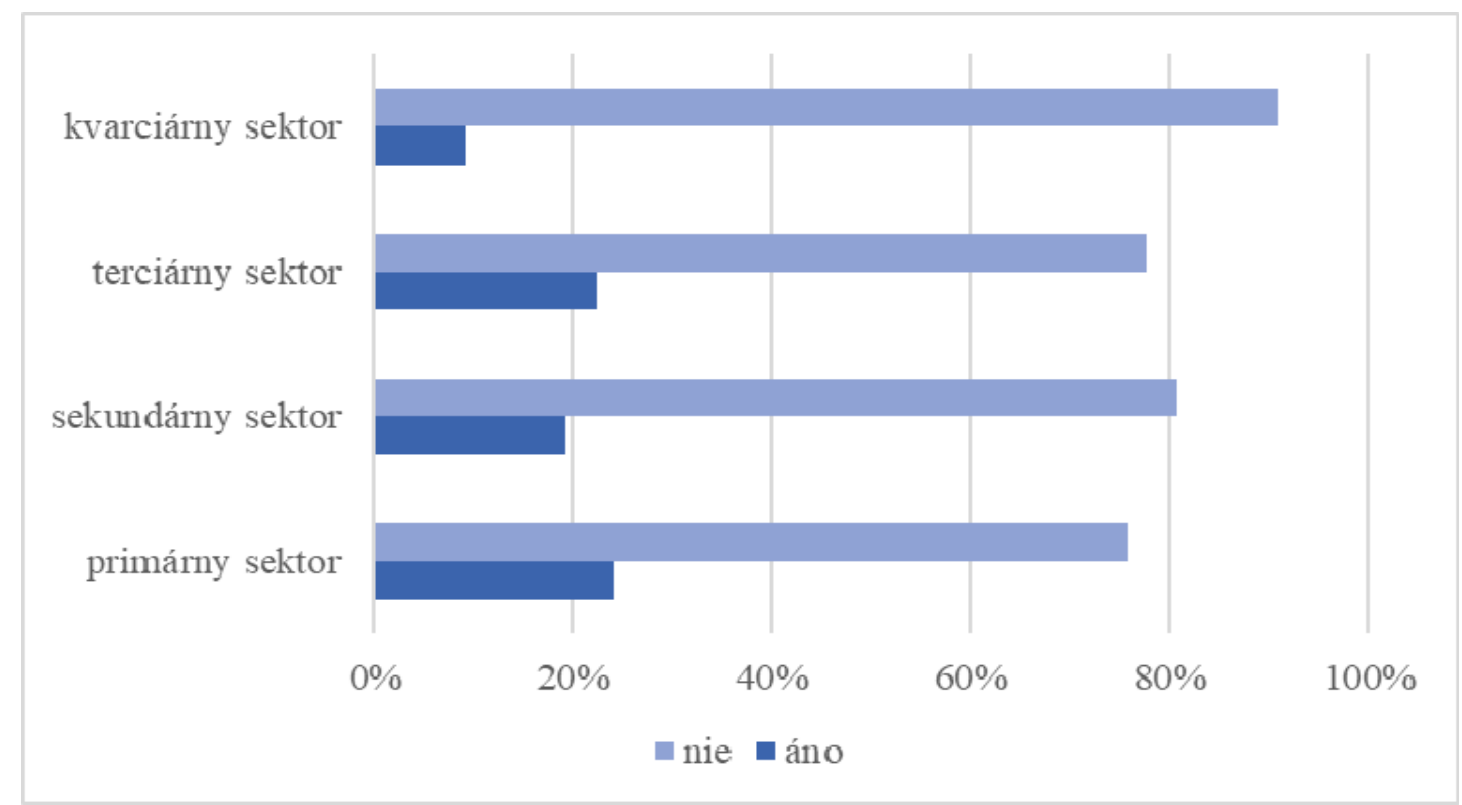

Obrázok 3 Predpoklady d’alšieho prepúšt’ania zamestnancov.

Zdroj: vlastné spracovanie.

$\mathrm{Na}$ zmiernenie ekonomických dopadov boli zo strany vlády pripravené viaceré opatrenia zamerané napríklad na podporu zachovania pracovných miest a podporu podnikatel'ov udržat' svoju činnost' aj napriek obmedzeniu obchodných aktivít či poklesu tržieb. Z výsledkov prieskumu vyplýva, že väčšie percento zamestnávatel’ov v primárnom a kvarciárnom sektore nepožiadalo o pomoc v rámci vládnych opatrení. V primárnom sektore $66 \%$ opýtaných zamestnávatel'ov nepožiadalo o pomoc a v kvarciárnom $64 \%$ zamestnávatel'ov. V sekundárnom a terciárnom sektore väčšie percento zamestnávatel'ov o pomoc zo strany štátu požiadalo (Obrázok 4).

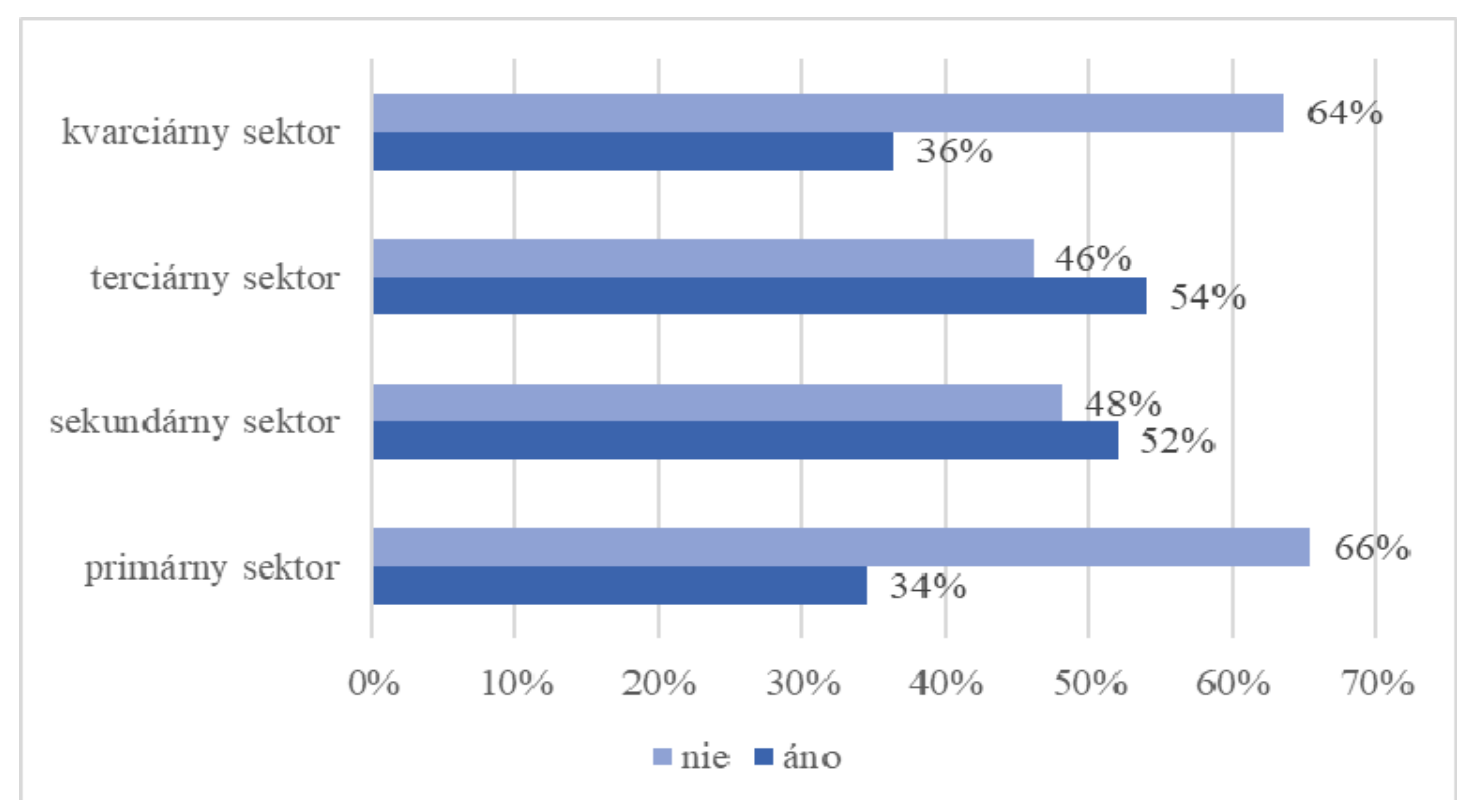

Obrázok 4 Využitie pomoci v rámci vládnych opatrení na podporu zamestnanosti.

Zdroj: vlastné spracovanie. 
Zamestnávatelia, ktorí požiadali o pomoc v rámci vládnych opatrení, najčastejšie využívali finančné príspevky na mzdy pri udržaní pracovného miesta, a to $28 \%$ zamestnávatel'ov v primárnom sektore, 49\% zamestnávatel'ov v sekundárnom sektore, 42\% zamestnávatel'ov v terciárnom sektore a 33\% zamestnávatel'ov v kvarciárnom sektore. Zamestnávatelia $\mathrm{v}$ primárnom sektore najviac využívali pandemické nemocenské a pandemické ošetrovné ( $31 \%$ zamestnávatel'ov), zamestnávatelia v sekundárnom sektore najviac využívali finančný príspevok na mzdy pri udržaní pracovného miesta (49\% zamestnávatel'ov), zamestnávatelia $\mathrm{v}$ terciárnom sektore rovnako najviac využívali finančný príspevok na mzdy pri udržaní pracovného miesta (42\% zamestnávatel'ov) a zamestnávatelia v kvarciárnom sektore najviac využívali finančný príspevok na mzdy pri udržaní pracovného miesta a pandemické nemocenské a pandemické ošetrovné ( $33 \%$ zamestnávatel’ov).

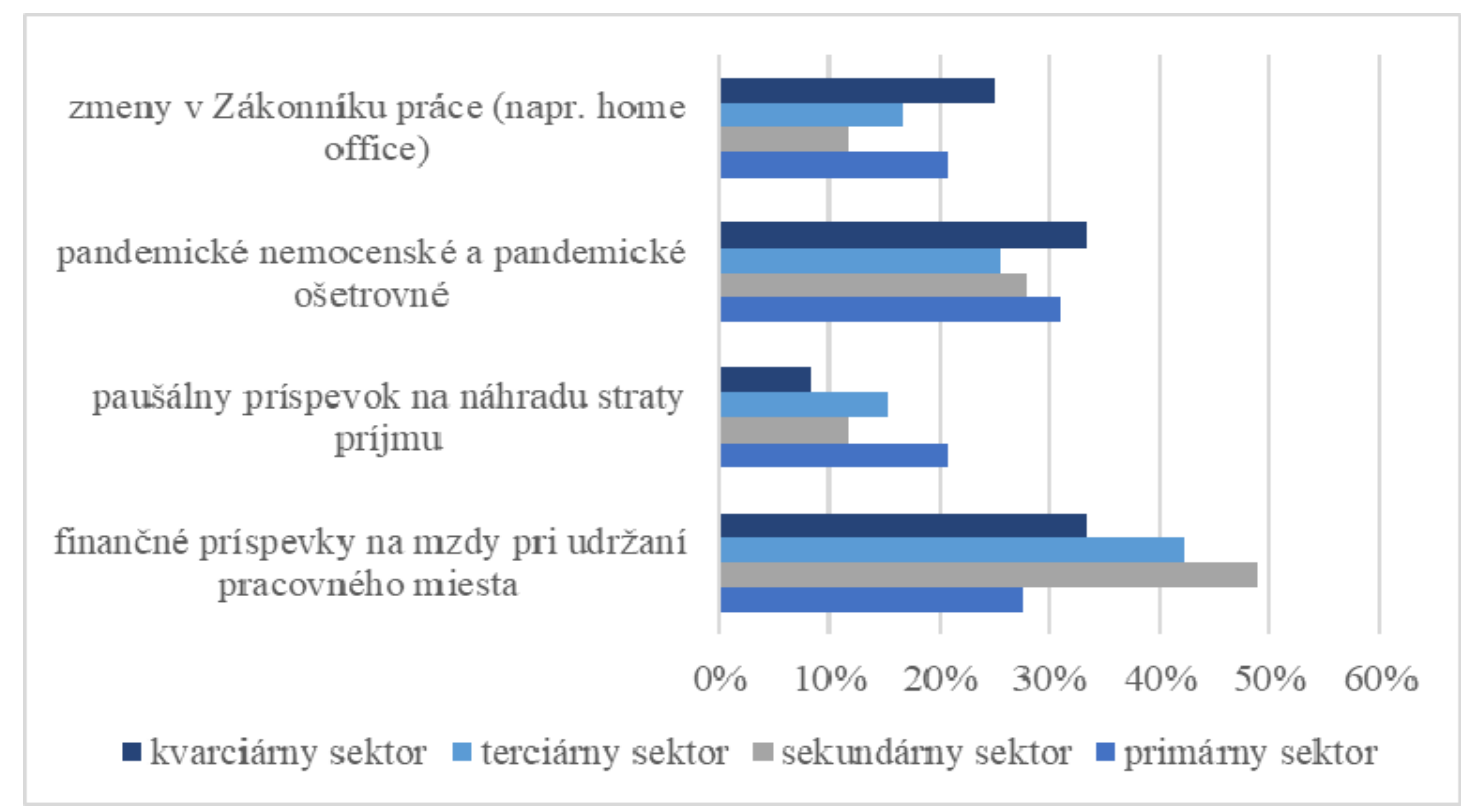

Obrázok 5 Využívané formy pomoci v rámci vládnych opatrení. Zdroj: vlastné spracovanie.

Podl'a prieskumu Národného podnikatel'ského centra však zamestnávatelia očakávajú výraznejšiu pomoc, pretože pomoc od štátu nevykompenzovala výpadok tržieb a straty, s ktorými sa musia podnikatelia vysporiadat' a pokles tržieb bol výrazne vyšší ako poskytnutá pomoc od štátu, čo v rámci prieskumu Národného podnikatel'ského centra potvrdilo až $49 \%$ opýtaných zamestnávatel'ov. [9]

Väčšina zamestnávatel'ov v primárnom sektore (62\%) predpokladá zotavenie z pandemickej situácie do 2 rokov, rovnaký predpoklad uvádzajú aj zamestnávatelia v sekundárnom (69\%) a terciárnom (67\%) sektore. Väčšina zamestnávatel’ov v kvarciárnom sektore predpokladá zotavenie z pandemickej situácie viac ako 2 roky (55\%). Výsledky predpokladov zotavenia zamestnávatel’ov z pandemickej situácie podl'a jednotlivých sektorov národného hospodárstva sú uvedené na obrázku 6. 


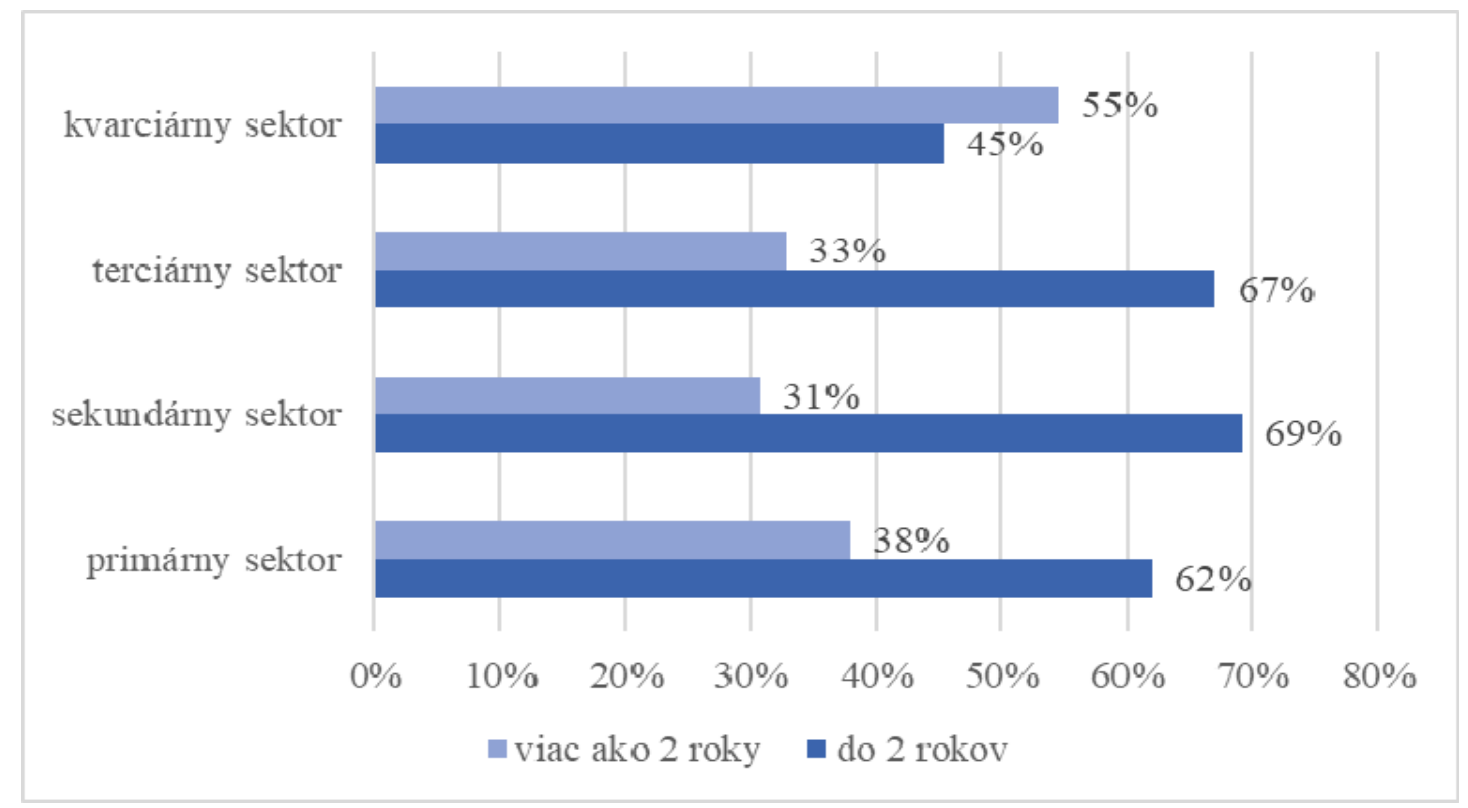

Obrázok 6 Predpoklady zotavenia z pandemickej situácie.

Zdroj: vlastné spracovanie.

\section{Záver}

Pandémia COVID-19 sa výrazne dotýka každodenného života l'udí, zamestnancov, zamestnávatel'ov a živnostníkov. Ciel’om článku bolo poukázat', aký dopad má pandémia na zamestnávatel'ov v jednotlivých sektoroch národného hospodárstva $\mathrm{z}$ pohl'adu zamestnanosti a tiež aké opatrenia boli zamestnávatel'mi využívané na udržanie zamestnanosti. Na základe zrealizovaného prieskumu a analýzy dostupnej literatúry možno konštatovat', že pandémia vo vel'kej miere ovplyvnila ekonomickú situáciu všetkých krajín. Dôsledky pandémie možno sledovat' aj na trhu práce. $\mathrm{Na}$ zmiernenie ekonomických dopadov pandémie boli zamestnávatelia $\mathrm{v}$ jednotlivých sektoroch národného hospodárstva nútení pristúpit' $\mathrm{k}$ znižovaniu miezd či obmedzeniu benefitov pre zamestnancov, $\mathrm{v}$ niektorých prípadoch až k prepúšt'aniu zamestnancov. Možno konštatovat', že zamestnávatelia v jednotlivých sektoroch využívali pomoc od štátu na udržanie zamestnanosti, avšak túto pomoc hodnotia ako nedostatočnú. V porovnaní s d'alšími krajinami, Slovensko prijalo podobné opatrenia ako okolité krajiny, ako napríklad práca z domu na zamedzenie šírenia pandémie. V súčasnosti je stále náročné predpokladat', aké dôsledky bude mat' pandémia na trh práce a samotných zamestnávatel'ov z dlhodobého hl'adiska. Väčšina zamestnávatel'ov však predpokladá, že budú schopní zotavit'sa z pandemickej situácie do 2 rokov.

\section{Literatúra}

[1] JEBRAN, K., CHEN, S., 2020. Can we learn lessons from the past? COVID-19 crisis and corporate governance responses. International Journal of Finance \& Economics. Doi: https://doi.org/10.1002/ijfe.2428.

[2] HUANG, J. a kol., 2020. Quantifying the Economic Impact of CoVID-19 in Mainland China Using Human Mobility Data. Cornell University. Dostupné na: https://arxiv.org/abs/2005.03010.

[3] FANA, M. a kol., 2020. Employment impact of Covid-19 crisis: from short term effects to long terms prospects. Journal of Industrial and Business Economics, vol. 47, str. 391 410. Doi: https://doi.org/10.1007/s40812-020-00168-5. 
[4] AL-FADLY, A., 2020. Impact of COVID-19 on SMES and Employment. Entrepreneurship and sustainability issues, vol. 8, no. 2, str. 629-648. Doi: https://doi.org/10.9770/jesi.2020.8.2(38).

[5] LORD, P., 2020. Changing world, changing work. Contemporary social science, vol 15, no. 4,4 str. $407 \quad$ - 415.4 Dostupné na: https://www.tandfonline.com/doi/pdf/10.1080/21582041.2020.1812707?needAccess=true\&.

[6] INTERNATIONAL LABOUR ORGANIZATION, 2020. COVID-19: Guidance for labour statistics data collection. Dostupné na: https://ilo.org/wcmsp5/groups/public/--dgreports/---stat/documents/publication/wcms 747075.pdf.

[7] BÉLAND, L. P. a kol., 2020. The short-term economic consequences of COVID-19: exposure to disease, remote work and government response. Institute of Labor Economics. Dostupné na: https://www.iza.org/publications/dp/13159/the-short-termeconomic-consequences-of-covid-19-exposure-to-disease-remote-work-and-governmentresponse.

[8] PALOMINO, J. C. a kol., 2020. Wage inequality and poverty effects of lockdown and social distancing in Europe. Institute for New Economic Thinking at the Oxford Martin School.

Dostupné

na: https://www.inet.ox.ac.uk/files/Lockdown inequality Palomino Rodriguez Sebastian WP.pdf.

[9] NÁRODNÉ PODNIKAELSKÉ CENTRUM, 2020. Výsledky prieskumu názorov podnikatel'ov na dopady druhej vlny koronakrízy. Dostupné na: https://www.npc.sk/sk/podnikanie-v-koronakrize/vysledky-prieskumu-nazorov-podnikatelov-nadopady-druhej-vlny-koronakrizy/.

[10] SLOVAK BUSINESS AGENCY, 2020. Vplyv pandémie COVID-19 na zamestnanost' na Slovensku. Dostupné na: http://www.sbagency.sk/vplyv-pandemie-covid-19-nazamestnanost-na-slovensku.

[11]NÁRODNÁ BANKA SLOVENSKA, 2020. Mesačný bulletin NBS. December 2020. Dostupné na: https://www.nbs.sk/ img/Documents/ MesacnyBulletin/2020/protected/mb1220.pdf.

[12] MINISTERSTVO PRÁCE, SOCIÁLNYCH VECÍ A RODINY SR, 2020. Prvá pomoc zamestnávatel'om, zamestnancom a živnostníkom. Dostupné na: https://www.pomahameludom.sk/.

\section{Grantová podpora}

VEGA 1/0518/19 Výskum dopadov rozvoja digitálnej ekonomiky na konkurencieschopnost' podnikov v znalostnej spoločnosti. 